\title{
MORPHACTIN SUBSTANTIALLY INDUCED THE FOURTH INTERNODE GROWTH IN DECAPITATED TULIPS: RELEVANCE TO ENDOGENOUS LEVELS OF INDOLE-3-ACETIC ACID
}

\author{
Junichi Ueda ${ }^{1}$, Justyna Góraj ${ }^{2}$, \\ Elżbieta Węgrzynowicz-Lesiak ${ }^{2}$, Kensuke Miyamoto ${ }^{3}$ \\ and Marian Saniewski ${ }^{2}$ \\ ${ }^{1}$ Department of Biological Science, Graduate School of Science
} Osaka Prefecture University, 1-1 Gakuen-cho, Naka-ku, Sakai, Osaka 599-8531, JAPAN

${ }^{2}$ Research Institute of Horticulture

Konstytucji 3 Maja 1/3 96-100 Skierniewice, POLAND

${ }^{3}$ Faculty of Liberal Arts and Sciences, Osaka Prefecture University

1-1 Gakuen-cho, Naka-ku, Sakai, Osaka 599-8531, JAPAN

(Received October 24, 2012/Accepted November 30, 2012)

\section{A B S T R A C T}

Important role of auxin polar transport inhibitors such as TIBA (2,3,5triiodobenzoic acid), NPA ( $N$-(1-naphthyl)phthalamic acid) and morphactin (methyl 2-chloro-9-hydroxyfluorene-9-carboxylate) in stem growth of tulips was intensively studied. After the application of morphactin above the $3^{\text {rd }}$ node of decapitated tulips, the stimulated growth of the $4^{\text {th }}$ internode was clearly observed. On the other hand, NPA and TIBA were slightly effective in stimulating the $4^{\text {th }}$ internode growth of tulips. Endogenous levels of IAA in the $4^{\text {th }}$ internode after the treatment of auxin polar transport inhibitors were determined using gas-liquid chromatography-mass spectrometry (GC-MS) and gas-liquid chromatography-mass spectrometry selected ion monitoring system (GC-SIM) with deuterium labelled IAA (Indole-2,4,5,6,7- $\mathrm{d}_{5}-3$ acetic acid, $\mathrm{d}_{5}$-IAA) as an internal standard, resulted in significant accumulation of IAA in the 4th internode of tulips after the treatment of morphactin. In the treatment of NPA and TIBA, there was almost no such an accumulation of IAA. These results strongly suggest that stimulated growth of the $4^{\text {th }}$ internode of tulips induced by the application of morphactin is the consequence of accumulated endogenous levels of IAA after the treatment. The possible mode of action of auxin polar transport inhibitors in tulip stem growth is also discussed. 


\section{J. Ueda et al.}

Abbreviations: GC-MS - gas-liquid chromatography-mass spectrometry, GC-SIM gas-liquid chromatography-mass spectrometry selected ion monitoring system, IAA indole-3-acetic acid, NPA - N-(1-naphthyl)phthalamic acid, TIBA - 2,3,5-triiodobenzoic acid

Key words: deuterium labelled IAA, endogenous levels of IAA, growth, internodes, stem, morphactin, NPA, TIBA, tulips

\section{INTRODUCTION}

Rapid elongation of the $4^{\text {th }}$ (top) internode in tulips takes place after earlier elongation of the first, second and third internodes (Ranwala and Miller, 2008). Elongation of the $4^{\text {th }}$ internode, after removal of the flower bud in growing tulips, with intact or removed leaves, at different stages of growth, was very weak (Saniewski et al., 2010). This suggests that the flower bud is always responsible for elongation of the $4^{\text {th }}$ internode. Exogenously applied auxin (IAA $0.1 \%$, w/w in lanolin paste) to the cut surface of tulip stem (in the place of removed tulip bud) with intact or removed leaves, resulted in greatly stimulated growth of the $4^{\text {th }}$ internode and lower internodes of tulip shoot (Saniewski and De Munk, 1981; Saniewski et al., 2010).

The elongation growth of the excised $4^{\text {th }}$ internode of tulip shoot with or without node, after removal of the flower bud was much higher, in comparison with that of the intact $4^{\text {th }}$ internode in tulip shoot which was growing and with that the $4^{\text {th }}$ internode which the flower bud had been cut (Saniewski et al., 2010). Elongation depended on the initial length of the $4^{\text {th }}$ internode.
The main question is why the growth of the excised $4^{\text {th }}$ internode, independently of the length - with or without node, is much higher than in tulips which are growing after removal of the flower bud? One possible explanation is that endogenous auxin in the $4^{\text {th }}$ internode in growing tulip shoot after removal of the flower bud, is easily transported basipetally to lower internodes. This transport takes place because there is an interaction between the growth of each internode in intact tulip shoot. Lack of endogenous auxin would then cause a limitation on the growth of the $4^{\text {th }}$ internode. The higher growth of the excised $4^{\text {th }}$ internode, in comparison to that in growing tulips after removal of the flower bud, is possibly caused by weaker and/or slow flow of auxin into water. Consequently, relative higher levels of endogenous auxin are still present in the $4^{\text {th }}$ internode, which accounts for the elongation. In addition, the growth rate of the excised $4^{\text {th }}$ internode with flower bud with different initial lengths greatly elongated. The results suggest again that flower bud is a source of auxin to induce the growth of the excised $4^{\text {th }}$ internode (Saniewski et al., 2010). 
In the present study we report that morphactin substantially stimulated the growth of the $4^{\text {th }}$ internode in growing tulips after removal of flower bud when it was applied above the $3^{\text {rd }}$ node or on the top of the $4^{\text {th }}$ internode. The possible role of accumulated endogenous IAA in the $4^{\text {th }}$ internode of tulips after the treatment of auxin polar transport inhibitors is also discussed.

\section{MATERIAL AND METHODS}

\section{Plant materials}

Bulbs of tulip (Tulipa gesneriana L. 'Apeldoorn') with circumference of $10-11 \mathrm{~cm}$, after lifting, were stored at $19-22{ }^{\circ} \mathrm{C}$ until transferred on October 15 to $5{ }^{\circ} \mathrm{C}$ for dry cooling or planted in field conditions. During February, after full cooling of bulbs in $5{ }^{\circ} \mathrm{C}$, tunics were removed and the bulbs were individually planted in pots and cultivated at $18-20{ }^{\circ} \mathrm{C}$ in a greenhouse under natural light conditions. At different stage of tulips, when the length of the $4^{\text {th }}$ internode ranged between $25 \mathrm{~mm}$ to 60 $\mathrm{mm}$, flower buds were removed and lanolin only was applied on the top of the $4^{\text {th }}$ internode, and inhibitors of auxin polar transport, NPA, TIBA and morphactin, at a concentration of $0.2 \%$ in lanolin paste and lanolin only (as a control) were applied above the $3^{\text {rd }}$ node, below the $3^{\text {rd }}$ node and on the top of the $4^{\text {th }}$ internode, respectively. Detail initial length of the $4^{\text {th }}$ internode and lower internodes at time of treatment in all experiments (Exp. 1-6) are presented in the Table 1. The length of all internodes was measured at different period of duration of experiments, but always all internodes after final growth. Ten plants were used per treatment in all experiments and experiments were repeated two to three times. The analysis of variance and Duncan's t-test were used to estimate the difference between means of the length of $4^{\text {th }}$ internode at $p=0.05$.

Determinations of endogenous levels of IAA after treatment above the $3^{\text {rd }}$ node with NPA, TIBA and morphactin at a concentration of $0.2 \%$ in lanolin paste and lanolin only (as a control), applied over the $3^{\text {rd }}$ node when the length of the $4^{\text {th }}$ internode was $58 \mathrm{~mm}$, were made on tulips planted in field conditions. Treatments were made on April 17, ten plants per treatments were used. Determinations of endogenous IAA in the $4^{\text {th }}$ internode were made in the samples fixed on April 17 (initial sample) and in the samples treated with NPA, TIBA, morphactin and control (lanolin only) fixed on April 23. For fixation was used $80 \%$ methanol. The length of the $4^{\text {th }}$ internode on April 23 was following: Control (lanolin only) - $59 \mathrm{~mm}$, NPA - $61 \mathrm{~mm}$, TIBA - 63 mm, morphactin $-83 \mathrm{~mm}$.

\section{Identification and determination of endogenous levels of IAA}

Extraction and solvent fractionation

Plant material was extracted with methanol and ethanol two times at $-20{ }^{\circ} \mathrm{C}$ for several weeks. Extracts were combined and evaporated in vacuo to give a small volume of aqueous solution. Indole-2,4,5,6,7$\mathrm{d}_{5}$-3-acetic acid $\left(\mathrm{d}_{5}\right.$-IAA) was added to the aqueous solution as an internal 
standard at a rate of $40-50 \mathrm{ng} / \mathrm{g}$ dry weight. The aqueous solution containing $\mathrm{d}_{5}$-IAA was adjusted to $\mathrm{pH} 3$ with $\mathrm{HCl}$ and then partitioned two times against water-saturated diethyl ether in the usual way (Yokota et al., 1980, Ueda et al., 1991), giving the diethyl ether soluble-acidic materials including IAA. Acidic diethyl ether fraction was dried over anhydrous $\mathrm{Na}_{2} \mathrm{SO}_{4}$ and then concentrated to dryness in vacuo. Partial purification was performed with silica gel thinlayer chromatography (TLC) developed with the solvent of $n$-hexaneethyl acetate-chloroform-acetic acid (40 : $40: 16: 1, \mathrm{v} / \mathrm{v} / \mathrm{v} / \mathrm{v}$, multiple development). Zone corresponding to that of authentic IAA was scraped off and eluted with ethyl acetate for an appropriate time in low temperature. Eluate of ethyl acetate was evaporated to dryness in vacuo.

Identification and estimation of IAA using a gas-liquid chromatographymass spectrometry (GC-MS)

Partially purified sample was dissolved in a small amount of ethyl acetate again and then methylated with ethereal diazomethane. Methylated samples were subjected to a Finnigan GCQ gas-liquid chromatography-mass spectrometry (GCMS) and/or gas-liquid chromatography-mass spectrometry selected ion monitoring system (GC-SIM) as already reported (Ueda et al., 1991). In GC-SIM analyses, two prominent fragment ions of $\mathrm{m} / \mathrm{z} 189$ (molecular ion $\left.\left[\mathrm{M}^{+}\right]\right), 130$ (base peak) for $\mathrm{d}_{0^{-}}$ IAA methyl ester and m/z 194 (molecular ion $\left[\mathrm{M}^{+}\right]$) and 135 (base peak) for $\mathrm{d}_{5}$-IAA one were monitored. Carrier gas was $\mathrm{He}\left(4 \mathrm{~kg} / \mathrm{cm}^{2}\right)$ and ionizing voltage was $70 \mathrm{eV}$. Column temperature was 160 for $1 \mathrm{~min}$ and then was increased to 250 for $7.75 \mathrm{~min}$ at a rate of $8 / \mathrm{min}$, and it was kept at 250 for $11.25 \mathrm{~min}$. Total time of the program was $20 \mathrm{~min}$.

All results were expressed as $\mu \mathrm{g} /$ total dry weight of the sample.

\section{RESULTS AND DISCUSSION}

\section{Effects of auxin polar transport inhibitors on the growth of tulip stem}

After application of morphactin above the $3^{\text {rd }}$ node, the inhibitor is translocated both basipetally (to the $3^{\text {rd }}$, the $2^{\text {nd }}$, the $1^{\text {st }}$ internodes) and acropetally (to the $4^{\text {th }}$ internode) and finally the growth of the $4^{\text {th }}$ internode is stimulated (Exp. 1: initial length of the $4^{\text {th }}$ internode on Feb. $08-40 \mathrm{~mm}$ : Fig. 1, Table 1; Exp. 2: initial length of the $4^{\text {th }}$ internode on Feb. $0.8-$ $60 \mathrm{~mm}$ : Table 1). Thus, transport of auxin was inhibited by morphactin at the place of treatment and in entire the $4^{\text {th }}$ internode.

When morphactin was applied in the place of removed flower bud (Exp. 3: initial length of the $4^{\text {th }}$ internode on Feb. $08-50 \mathrm{~mm}$ : Table 1; Exp. 4: initial length of the $4^{\text {th }}$ internode on April 08 - 46 mm: Fig. 2, Table 1) morphactin stimulated the growth of the $4^{\text {th }}$ internode. In this case morphactin is transported only basipetally and probably the transport of morphactin thought to be faster than auxin in the $4^{\text {th }}$ internode and finally accumulation of auxin takes place on the $4^{\text {th }}$ internode. 
Morphactin substantially induced the fourth internode..

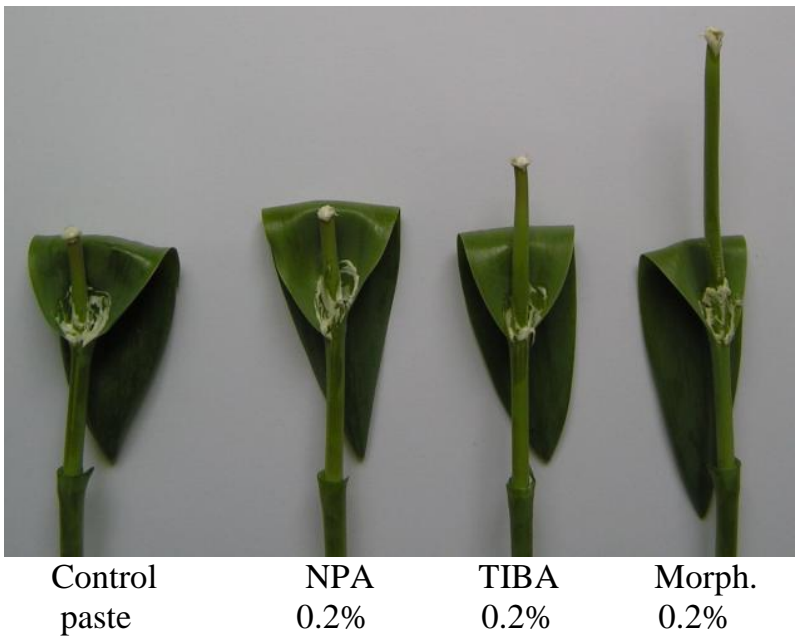

Figure 1. The effect of Morphactin, NPA and TIBA at a concentration of $0.2 \%$, applied above the $3^{\text {rd }}$ node, after excision of flower bud, on the growth of the $4^{\text {th }}$ internode in tulips (Exp. 1, see Table 1); leaves were removed before picture was made

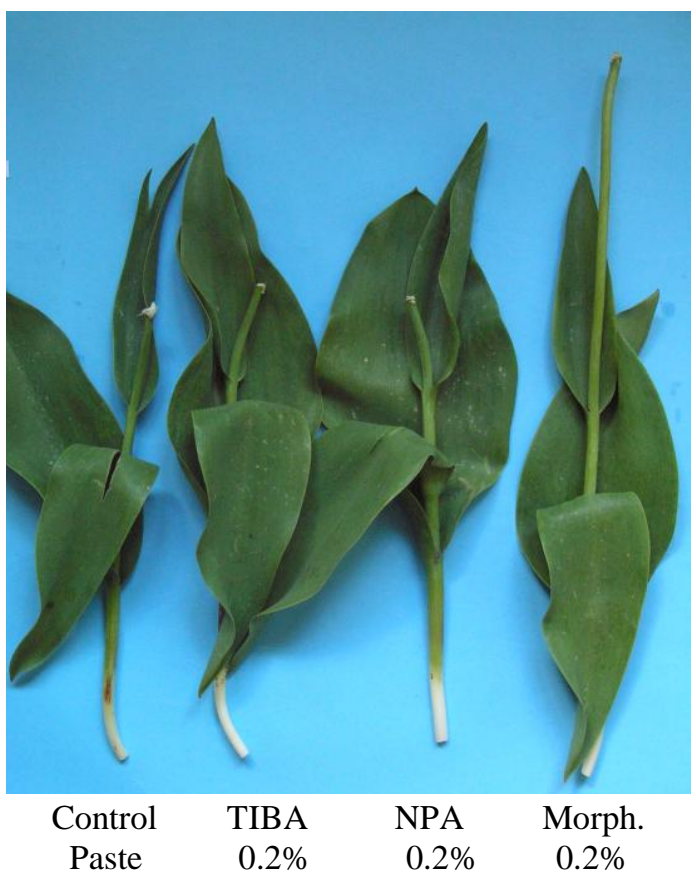

Figure 2. The effect of Morphactin, NPA and TIBA at a concentration of $0.2 \%$, applied in the place of removed flower bud, on the growth of the $4^{\text {th }}$ internode in tulips (Exp. 4, see Table 1) 
J. Ueda et al.

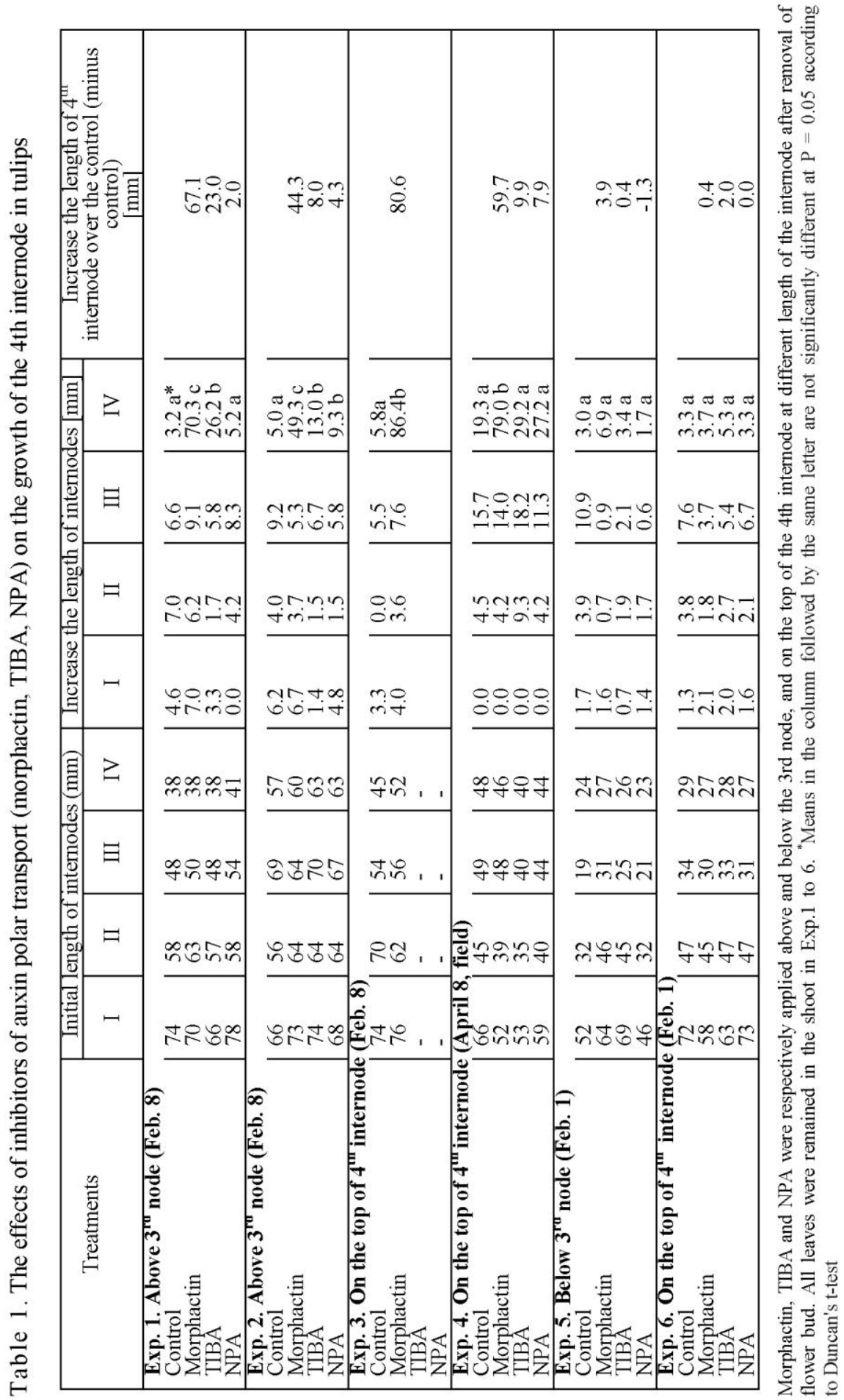


When morphactin was applied in the place of removed flower bud in case of small length of the $4^{\text {th }}$ internode (Exp. 6: initial length of the $4^{\text {th }}$ internode on Feb. $01-26 \mathrm{~mm}$ : Table 1) we did not observe stimulation of growth of the $4^{\text {th }}$ internode. It is possible that in this case endogenous levels of auxin was extremely low since the length of the $4^{\text {th }}$ internode was too short and finally morphactin did not stimulate the growth of the $4^{\text {th }}$ internode; almost no auxin and no action of morphactin.

When morphactin was applied below the $3^{\text {rd }}$ node with short length of the $4^{\text {th }}$ internode (Exp. 5: initial length of the $4^{\text {th }}$ internode on Feb. $01-$ $27 \mathrm{~mm}$ : Table 1), the stimulatory effect of morphactin was significant but the increase of growth was very low.

The effects of NPA and TIBA on the growth of $4^{\text {th }}$ internode in all these experiments were very small, independently from place of the treatment.

\section{Endogenous levels of auxin in tulip stems after the treatment of auxin polar transport inhibitors}

Identification of IAA in the extract of tulip stem segments was made by GC-MS analysis. The prominent fragment ions of $\mathrm{m} / \mathrm{z} 135$ and $194\left(\mathrm{~d}_{5}\right.$-IAA methyl ester), and $\mathrm{m} / \mathrm{z} 130$ and $189\left(\mathrm{~d}_{0}\right.$-IAA methyl ester) were observed at the retention time of $7.18 \mathrm{~min}$ and $7.21 \mathrm{~min}$, respectively, indicating that the retention time of $\mathrm{d}_{5}$-IAA methyl ester is just only short compared to that of $\mathrm{d}_{0}$-IAA one. From these results, IAA was substantially identified in the acidic acid diethyl ether fractions of tulip stem segments. To estimate endogenous levels of IAA in tulip stem segments, GC-SIM analyses were introduced. Two prominent peaks of $\mathrm{m} / \mathrm{z} 194\left(\mathrm{~d}_{5}\right.$-IAA methyl ester) and 189 ( $\mathrm{d}_{0}$-IAA methyl ester) were used to determine endogenous levels of IAA in tulip stem segments. As shown in Fig. 3, endogenous levels of IAA rapidly decreased after removal flower buds in tulips. Endogenous levels of IAA in the $4^{\text {th }}$ internode in the treatment of morphactin applied at the 3rd node of tulips was highest among the samples after the treatment of auxin polar transport inhibitors (Fig. 3), suggesting strongly that polar transport of endogenous IAA produced in pistils (Xu et al., 2008) was almost completely inhibited by the application of morphactin compared to that of NPA and TIBA.

Saniewski and WęgrzynowiczLesiak (1993) have reported that a continuous supply of auxin is necessary for tulip stem growth. Xu et al. (2008) examined diffusible IAA, from various parts of tulips, during rapid elongation of the flower stalk using GC-MS. The amount of diffusible IAA from different organs followed the order of that of the internodes $>$ flower organs $>$ leaves at that time. The $4^{\text {th }}$ internode exported higher quantity of IAA than did the flower during most of the rapid elongation period, except of the beginning of the rapid elongation stage and on one day after flowering. They also suggested, that the top (the $4^{\text {th }}$ internode) was probably more important 


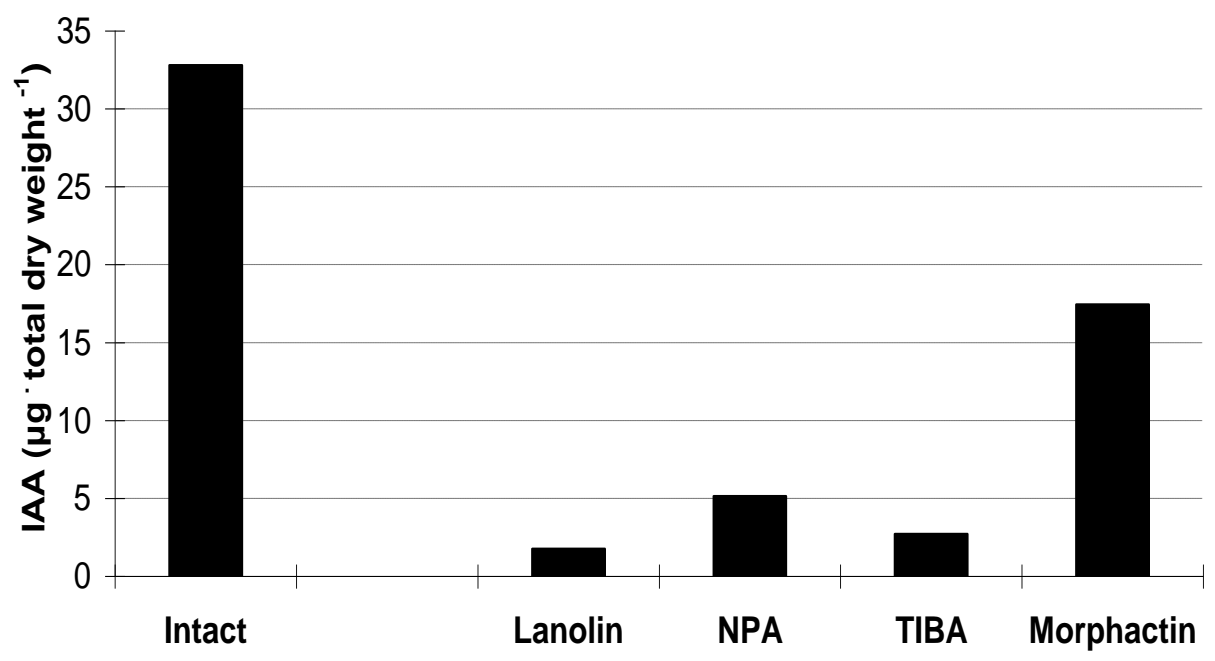

Figure 3. Endogenous levels of IAA in the $4^{\text {th }}$ internodes in Intact (fixed on April 17) and decapitated tulips treated with Lanolin only (control), NPA, TIBA and Morphactin (fixed on April 23). Determination procedures of endogenous levels of IAA are described in MATERIAL AND METHODS

than the flower, in the production of IAA accountable for rapid elongation of the flower stalk. Xu et al. (2008) also described that it is possible that before the beginning of the rapid elongation stage, the flower exudes higher levels of IAA than does each internode, acting as the major source of auxins.

Indole-3-acetic acid moves out of plant cells thorough an efflux carrier apparatus that is sensitive to synthetic inhibitors of auxin transport, NPA, TIBA and morphactin, but the mechanism by which auxin transport inhibitors control auxin efflux is not fully known (Muday and DeLong, 2001). It is no doubt fact that NPA inhibits IAA transport by specific binding to so-called NPA receptor, thereby blocking the carrier-mediated efflux of IAA; IAA does not compete with NPA for binding sites and NPAbinding site is important for auxin transport (Lomax et al., 1995; Ruegger et al., 1997; Muday et al., 1993). The binding site of morphactin has been controversial. It has been also shown that morphactin binds to NPA receptor, suggesting that morphactin inhibits polar IAA transport by the same mechanism as NPA (Sussman and Goldsmith, 1981; Thomson and Leopold, 1974). Some authors suggest that NPA and TIBA have different binding sites and TIBA competes with IAA for the same binding sites (Thomson et al., 1973; Michalke et al., 1992). Moreover, it is suggested that TIBA is transported in a polar 
basipetal manner when NPA is not (Thomson et al., 1973). Same explanation will be possible to morphactin. It is believed that morphactin is translocated in plants basipetally as well as acropetally through both sieve tubes and xylem elements (Neumann et al., 1977; Sundberg et al., 1994), suggesting that morphactin is faster to move in plant tissues than TIBA and NPA as described above. Further intensive studies to clarify the mode of movement of auxin polar transport inhibitors will be required in near future.

It is possible to indicate that NPA and TIBA are much less in action as inhibitors of auxin polar transport than morphactin in tulip stem. It should be mentioned that stimulated growth of tulip stems induced by the application of morphactin is not a cause but a consequence of accumulated endogenous levels of IAA after morphactin treatment. Some other properties of morphactin might have direct influence on the growth of the $4^{\text {th }}$ internode as well. Further investigation relevance to this point will also be necessary.

Acknowledgement: This work was partially supported by JSPS KAKENHI Grant Number 23510260.

\section{REFERENCES}

Lomax T.L., Muday G.K., Rubery P.H. 1995. Auxin transport. In: Plant Hormones, ed. By P.J. Davis, Kluwer Academic Publishers, Dordrecht, The Netherlands, pp. 509-530.

Michalke W., Katekar G.F., Geissler A.E. 1992. Phytotropin-binding sites and auxin transport in Cucurbita pepo: evidence for two recognition sites. PLANTA 181: 254-260.

Muday G.K., Brunn S.A., Haworth P., Subramanian M. 1993. Evidence for a single naphthylphthalamic acid binding site on the zucchini plasma membrane. PLANT PHYSIOL. 103: 449-456.

Muday G.K., DeLong A. 2001. Polar auxin transport: controlling where and how much. TRENDS PLANT SCI. 6: 535542.

Neumann P.M., Doss R.P., Sachs R.M. 1977. A new laboratory method used for investigating the uptake, translocation and metabolism of bark banded morphactin by trees. PHYSIOL. PLANT. 39: 248-251.

Ranwala A.P., Miller W.B. 2008. Gibberellin-mediated changes in carbohydrate metabolism during flower stalk elongation in tulips. PLANT GROWTH REGUL. 55: 241-248.

Ruegger M., Dewey E., Hobbie L., Brown D., Bernasconi P., Turner J., Muday G., Estelle M. 1997. Reduced naphthylphthalamic acid binding in the tir3 mutant of Arabidopsis is associated with a reduction in polar transport and diverse morphological defects. PLANT CELL 9: 745-757.

Saniewski M., de Munk W.J. 1981. Hormonal control of shoot elongation in tulips. SCI. HORT., 5: 363-372.

Saniewski M., Góraj J., WęgrzynowiczLesiak E., Okubo H., Miyamoto K., Ueda J. 2010. Different growth of excised and intact fourth internode after removal of the flower bud in growing tulips: focus on auxin action. J. FRUIT ORNAM. PLANT RES. 18: 297-308.

Saniewski M., Węgrzynowicz-Lesiak E. 1993. Continuous supply of auxin is necessary for tulip stem growth. J. FRUIT ORNAM. PLANT RES. 1: 59-66.

Sundberg B., Tuominen H., Little C.H.A. 1994. Effects of the indole-3-acetic 
acid (IAA) transport inhibitors N-1naphtylphtalamic acid and morphactin on endogenous IAA dynamics in relation to compression wood formation in 1-year-old Pinus sylvestris (L.) shoots. PLANT PHYSIOL. 106: 469-476.

Sussman M.R., Goldsmith M.H.M. 1981. The action of specific inhibitors of auxin transport on uptake of auxin and binding of $\mathrm{N}$-naphthylphthalamic acid to a membrane site in maize coleoptiles. PLANTA 152: 13-18.

Thomson K.S., Hertel R., Muller S., Tavares J.E. 1973. 1-N-Naphthylphthalamic acid and 2,3,5triiodobenzoic acid. In-vitro binding to particulate cell fractions and action on auxin transport in corn coleoptiles. PLANTA 109: 337-352.

Thomson K.S., Leopold A.C., 1974. In vitro binding of morphactins and $1-\mathrm{N}$ - naphthylphthalamic acid in corn coleoptiles and their effect on auxin transport. PLANTA 115: 259-270.

Xu R.-Y., Niimi Y., Kojami K., 2008. Changes in diffusible idole-3-acetic acid from various parts of tulip plant during rapid elongation of the flower stalk. PLANT GROWTH REGUL. 54: 81-88.

Ueda J., Komaki M.K., Okada K., Shimura Y., 1991. Identification and quantitative distribution of indole-3-acetic acid in Brassica junco Czern. J. PLANT PHYSIOL. 137: 628-630.

Yokota T., Murofushi N., Takahashi N. 1980. Extraction, Purification, and Identification. In: MacMillan J. (ed.), Hormonal Regulation of Development I, Springer-Verlag, Berlin, Encyc. PLANT PHYSIOL. 9: 113-201.

\title{
MORFAKTYNA INDUKUJE WZROST CZWARTEGO MIĘDZYWĘŹLA W DEKAPITOWANYCH TULIPANACH: ZWIAZZEK Z ENDOGENNYM POZIOMEM KWASU INDOLILO-3-OCTOWEGO
}

\author{
Junichi Ueda, Justyna Góraj, \\ Elżbieta Węgrzynowicz-Lesiak, Kensuke Miyamoto \\ i Marian Saniewski
}

Rola inhibitorów polarnego transportu auksyny, takich jak kwas 2,3,5trójjodobenzoesowy (TIBA), kwas naftyloftalamowy (NPA) i morfaktyna (kwas metylo 2-chloro-9-karboksylowy) była intensywnie badana na wzrost łodygi tulipana. Traktowanie morfaktyną łodygi tulipana powyżej 3. węzła, po odcięciu pąka kwiatowego, powodowało stymulację wzrostu 4. międzywęźla. Z drugiej strony, inhibitory 
Morphactin substantially induced the fourth internode..

polarnego transportu, NPA i TIBA, przy takim samym traktowaniu, wywierały mały wpływ na wzrost 4. międzywęźla. Endogenny poziom IAA w 4. międzywęźlu, po traktowaniu inhibitorami polarnego transportu, morfaktyna, NPA i TIBA, określano stosując metodę GC-MS i GC-SIM ze znakowanym IAA (kwas indolo-2,4,5,6,7-d - $_{5}$-3octowy) jako standard wewnętrzny. Stwierdzono silną akumulację IAA w 4. międzywęźlu łodygi po traktowaniu morfaktyną. Traktowanie NPA i TIBA powodowało tylko niewielką akumulację IAA w 4. międzywęźlu. Otrzymane wyniki wskazują, że stymulacja wzrostu 4. międzywęźla pod wpływem morfaktyny jest konsekwencją akumulacji IAA w tym międzywęźlu. Możliwy sposób działania inhibitorów polarnego transportu auksyny we wzroście łodygi tulipana jest w pracy dyskutowany.

Słowa kluczowe: IAA znakowane deuterem, endogenny poziom IAA, wzrost, międzywęźla, łodyga, morfaktyna, IAA, NPA, TIBA, tulipan 